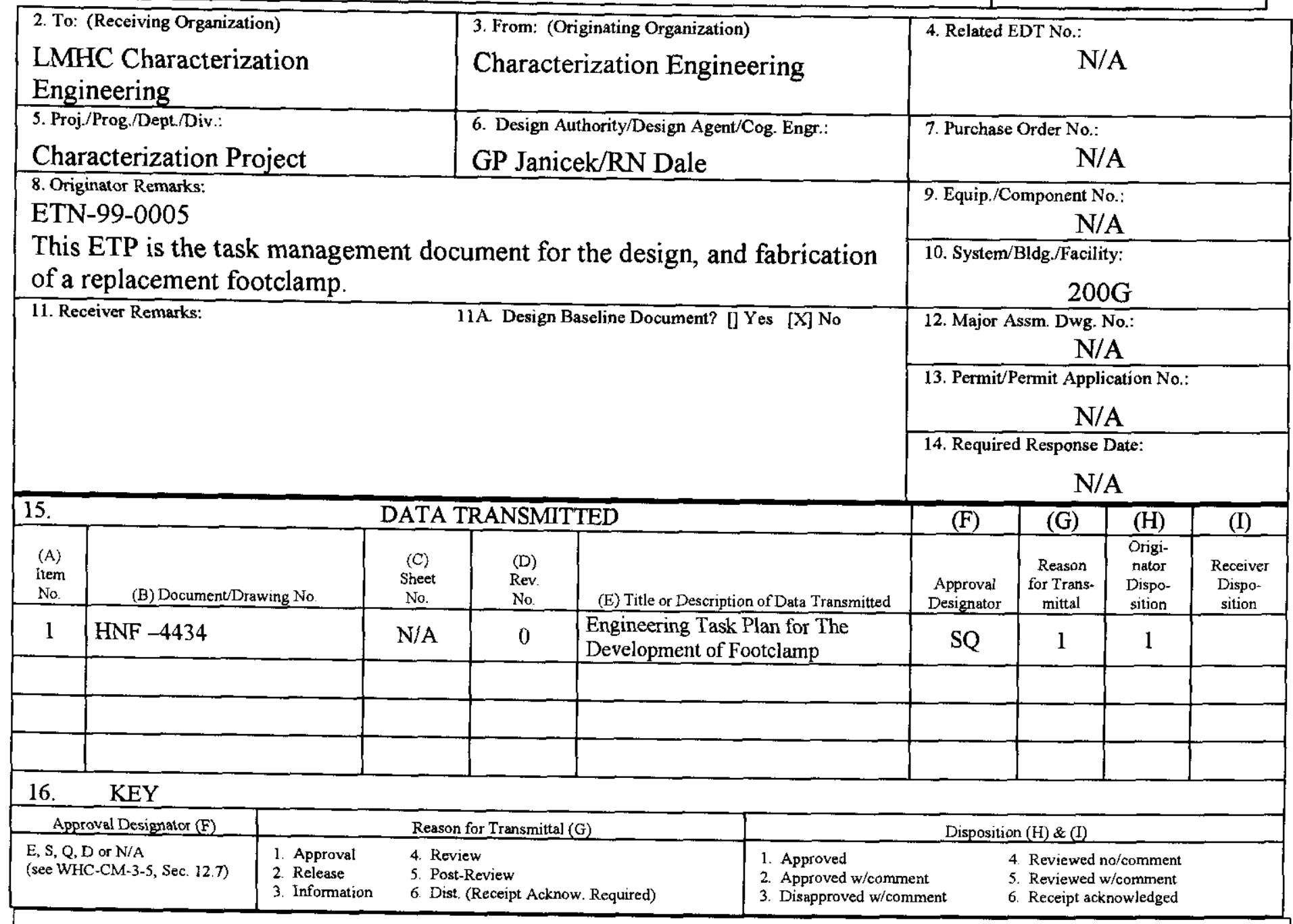

17. SIGNATURE/DISTRIBUTION

(See Approval Designator for required signatures)

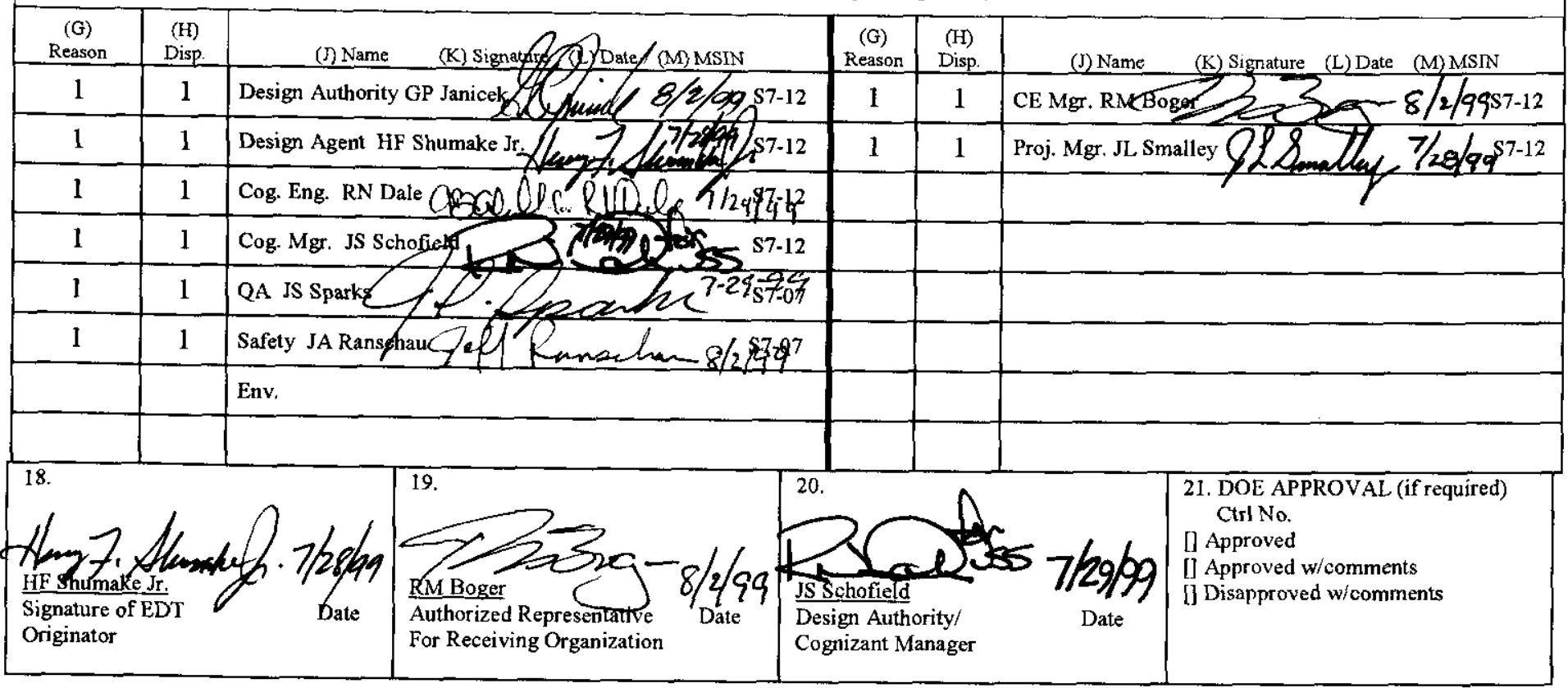




\title{
Engineering Task Plan for the Development of Footclamp
}

\section{RM Boger}

Prepared by Lockheed Martin Hanford, Inc.

Richland, WA 99352

U.S. Department of Energy Contract DE-AC06-96RL13200

$$
623417
$$

EDT/ECN: 623388.

Org Code: 74900

B\&R Code: EW3120074

UC: 2070

Charge Code: 102250/EI00

Total Pages: 17

Key Words: Waste Sampling, PMCS, RMCS, RMCST, Footclamp, Riser Equipment

\begin{abstract}
This Engineering Task Plan (ETP) is the management plan document for accomplishing the design, fabrication, and testing of a replacement footclamp assembly for the Push Mode Core Sampling Truck \#1 (PMCST) and the Rotary Mode Core Sampling Trucks 3 \& 4 (RMCST).
\end{abstract}

TRADEMARK DISCLAIMER. Reference herein to any specific commercial product, process, or service by trade name, trademark, manufacturer, or otherwise, does not necessarily constitute or imply its endorsement, recommendation, or favoring by the United States Government or any agency thereof or its contractors or subcontractors.

Primted in the United States of America. To obtain copies of this document, contact: Document Control Services, P.O. Box 950, Mailstop H6-08, Richland WA 99352, Phone (509) 372-2420; Fax (509) 376-4989.
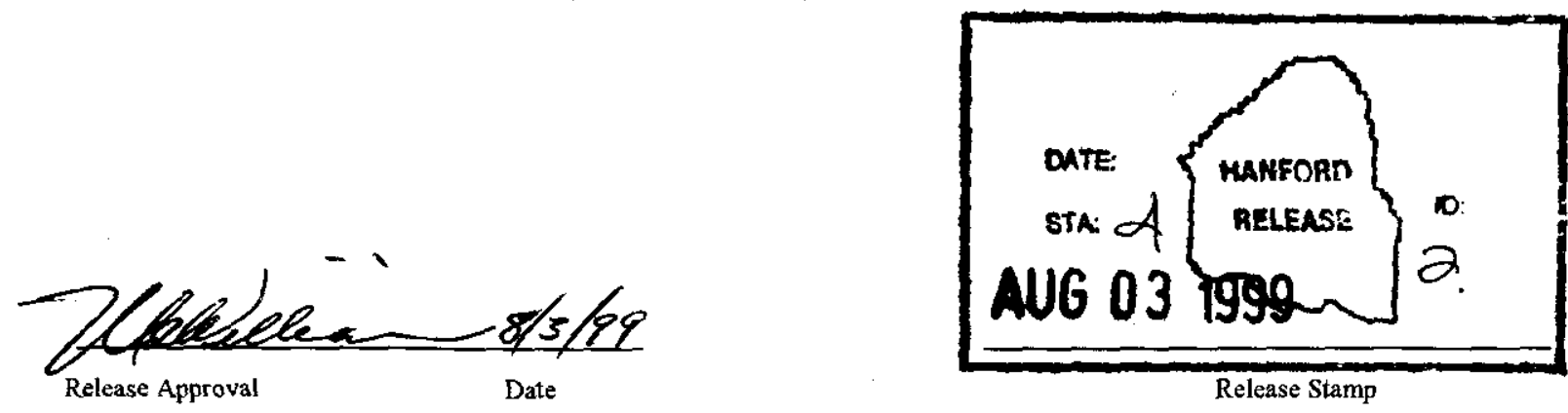

Approved for Public Release 


\title{
ENGINEERING TASK PLAN FOR THE DEVELOPMENT OF FOOTCLAMP
}

\author{
Prepared for \\ Lockheed Martin Hanford Corporation \\ Characterization Engineering
}

by

H. F. Shumake Jr.

COGEMA Engineering Corporation

July 1999 
TABLE OF CONTENTS

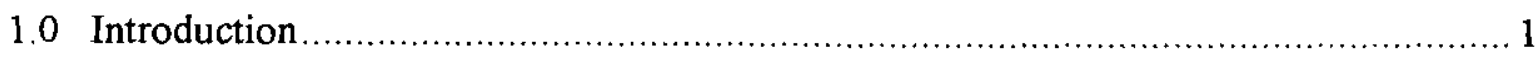

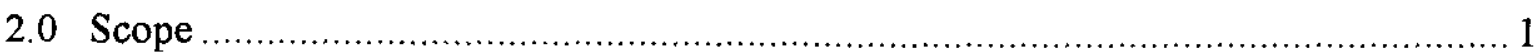

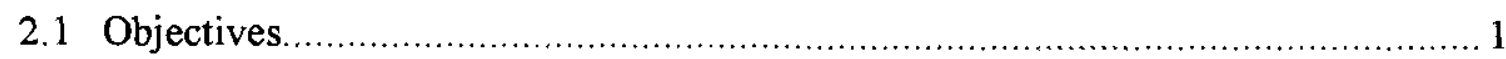

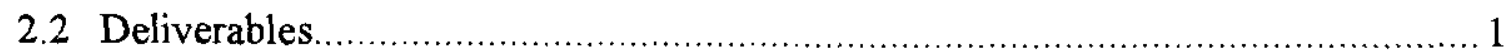

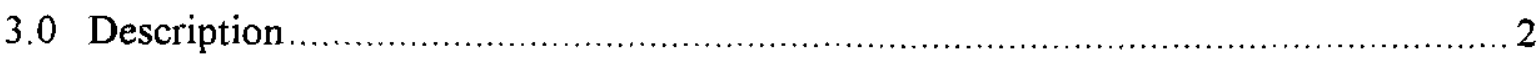

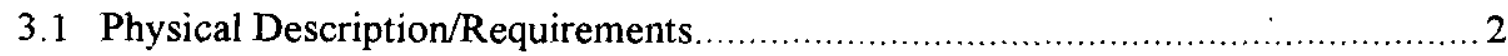

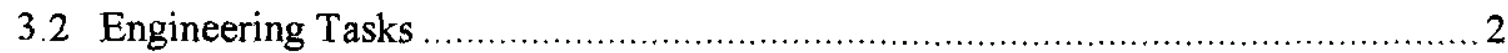

3.3 Verification and Technical Reviews and Modification Management ..................... 3

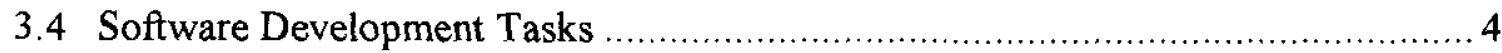

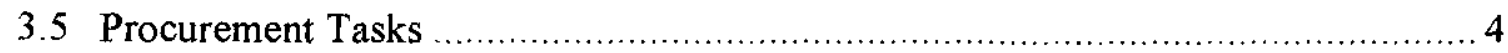

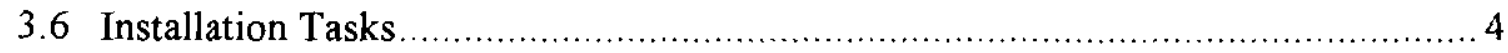

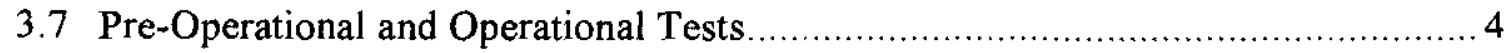

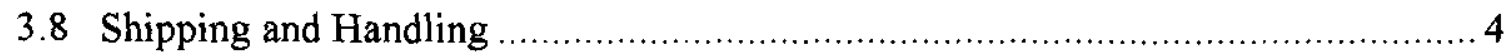

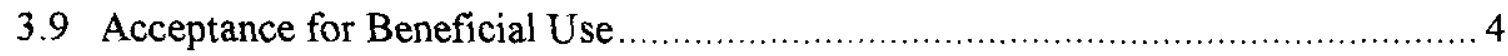

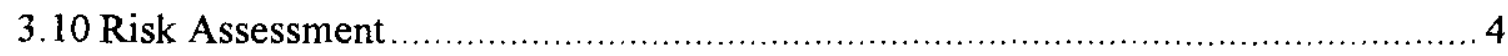

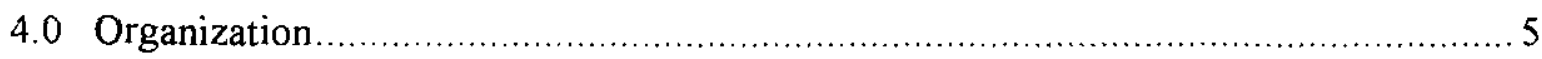

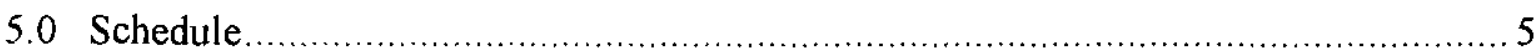

6.0 Cost Estimate

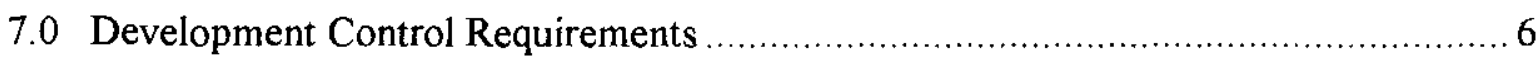

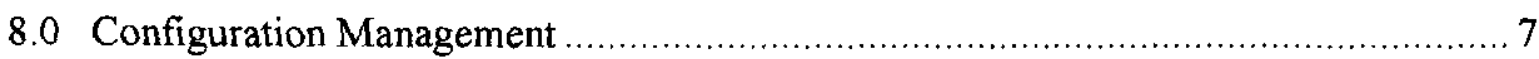

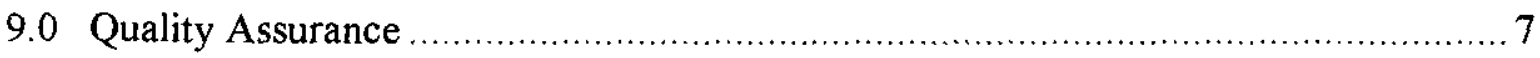

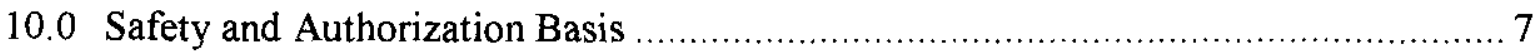

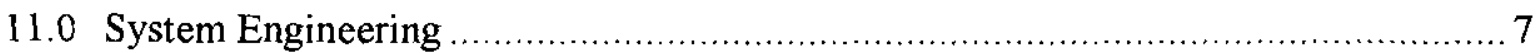

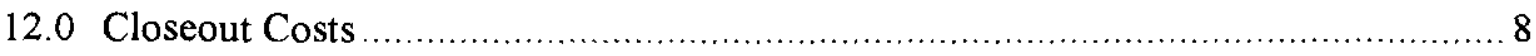

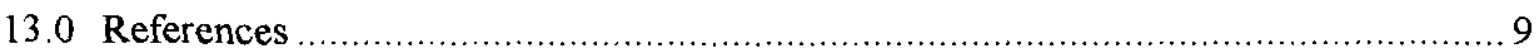

14.0 APPENDIX A-Acceptance for Benenficial Use ................................................ 11 


\subsection{INTRODUCTION}

The Rotary Mode Core Sampling Trucks (RMCSTs) currently use a footclamp that utilizes a wedge design to secure the drill string. On June 18,1998, a problem occurred while core sampling operations were being conducted. Approximately $28 \mathrm{ft}$. of drill string was inadvertently dropped into tank 241-SX-102. The root cause of this occurrence was determined to be inadequate or defective design of the footclamp being used. The footclamp in use during this occurrence relied on a wedge-type design that gripped the drill string tighter as the weight of the drill string was increased. The MAXIDRILL Model 3030 Footclamp does not rely on a wedge effect to hold the drill string; it uses spring force to engage the jaws with the drill string. The use of the MAXIDRILL Model 3030 Footclamp should eliminate any further problems of this nature and allow corrective action 2 in section 26 of the related occurrence report (RL-PHMC-TANKFARM-1998-0064) to be completed.

Modifications of the base of the MAXIDRILL Model 3030 Footclamp are necessary to decrease the possibility of an injury due to the exposed jaws. Also, the plan for sampling tank 241-Z-361 calls for a footclamp that will allow for total containment when the footclamp is connected to a tank riser. The need for a footclamp with total containment capabilities, and the design of a safer base for the MAXIDRILL Model 3030 Footclamp can be satisfied in the same task. The re-design of the base of the footclamp will allow for total containment while still being suitable for "normal" RMCS operations and improving the safety of the footclamp.

This Engineering Task Plan (ETP) is the management plan document for accomplishing the identified tasks. Any changes in scope of the ETP shall require formal direction by the Characterization Engineering manager.

This document shall also be considered the work planning document for development control per Development Control Requirements (HNF 1999a).

\subsection{SCOPE}

\subsection{OBJECTIVES}

The objectives of this task are to re-design the MAXIDRILL Model 3030 Footclamp, prepare fabrication and installation drawings, fabricate, assemble and perform acceptance testing for a footclamp assembly that has the desired safety characteristics for use by operations personnel during Rotary Mode Core Sampling (RMCS).

\subsection{DELIVERABLES}

This ETP will provide a footclamp that is fully documented, fabricated and tested, for acceptable use in accordance with applicable procedures. Deliverables will include, but 
not be limited to, fabrication drawings, fabrication and assembly of four footclamps, development test plan and development test report, and Acceptance for Beneficial Use.

NOTE: A total of four footclamps are to be built under this ETP, three of them will be fabricated for, and funded by, the 241-Z-361 sampling project. The fourth will be fabricated for, and funded by, Characterization Project Operations.

\subsection{DESCRIPTION}

\subsection{PHYSICAL DESCRIPTION/REQUIREMENTS}

The end result of this task will be an approved replacement footclamp assembly acceptable for use in core sampling operations. This replacement footclamp will provide a more reliable alternative than the current wedge-type footclamp for engaging and supporting the core sampling drill string. The re-designed MAXIDRILL Model 3030 Footclamp will allow for enhanced operator safety.

The footclamp assembly shall meet the following design criteria:

- The footclamp assembly shall meet all applicable requirements in the Baseline Design Compliance Matrix (DCM) for the Rotary Mode Core Sampling System (HNF 1998a).

- The footclamp shall support a minimum of 1000 pounds of vertical force applied to a piece of $2 \frac{1 / 4}{4}$ inch diameter, non-fluted; or $2^{1 / 2}$ inch diameter fluted drill string.

- The footclamp shall not open on loss of supply air pressure.

- The footclamp shall not deform either the $2 \frac{1 / 4}{4}$ inch diameter, non-fluted; or the $2 \frac{1 / 2}{2}$ inch diameter, fluted drill string preventing the sampling apparatus from passing through it.

- The measurement between the contact surfaces of the jaws of the footclamp, when in the closed, or engaged, position shall be less than $2 \frac{1 / 4}{4}$ in.

- The close rate of the jaws of the footclamp shall not exceed $1.0 \mathrm{fps}$.

- The footclamp, by design, shall prevent accidental insertion of appendages into mechanisms capable of inflicting injury.

- The footclamp shall interface with the pipe wiper (aka--"frisbee").

- The footclamp shall interface with the drill rod washer assembly.

\subsection{ENGINEERING TASKS}

Engineering services and deliverables provided by Characterization Engineering will include the following:

- Provide overall task management and schedule

- Prepare Development Test Plan and Report

- Perform Development Testing

- Provide day-to-day guidance of design services during generation of fabrication and installation drawings 
- Conduct design review as directed by Design Authority

- Provide engineering support during fabrication

- Generate Engineering Change Notices (ECNs) as required

- Provide engineering support during acceptance testing

- Update preventive maintenance procedures as required

- Update operation procedures as required

- Update Essential Drawing List (1998b) as required

- Update Drawing Evaluation Report (1998c) as required.

Fabrication will be performed to unreleased drawings which will be clearly marked "DEVELOPMENT CONTROL." The "redline" process will be used to document any necessary design changes. Day-to-day "redlines" shall be approved by the Design Authority or Cognizant Engineer, or authorized delegate as required by Development Control Requirements (HNF 1999a). After final approval by the Design Authority and Cognizant Engineer, all "redline" changes will be incorporated into the fabrication drawings prior to release. All drawings will be prepared, approved, and released per Engineering Drawing requirements (HNF 1999b). Any subsequent changes will be done per Engineering Document Change Control Requirements (HNF 1997a). All subsequent design media and engineering documentation generated in support of this task will reference Engineering Task Number ETN-99-0005

\subsection{VERIFICATION AND TECHNICAL REVIEWS AND MODIFICATION MANAGEMENT}

The design media requiring verification and review will include new fabrication drawings for the replacement footclamp and any subsequent design changes identified during fabrication. Design verification requirements for the new drawings and any ECNs will be determined on a case-by-case basis per Design Verification Requirements (HNF 1997b). The design verification method will be reviewed and approved by the Characterization Engineering Design Authority.

Technical review of documents will be completed per Review and Approval of Documents (HNF 1997c).

The current Safety Equipment List (SEL)(HNF1998e) classifies the footclamp as a safety class (SC) component. ECN 173679 removes the pneumatic footclamp from Table 6-1, FG/RMCS Credited Design Safety Features, of SAD-35 (WHC 1997). When Addendum Five of the Basis for Interim Operations (BIO) is approved, the SEL will be revised to reflect the BIO. Addendum Five of the BIO classifies the footclamp as General Service (GS) Defense in Depth (DID). The implementation of the new footclamp design and the release of Addendum Five of the BIO are projected to occur at approximately the same time, therefore this footclamp will be classified GS/DID. The BIO and its companion documents constitute the Authorization Basis for Hanford tank waste sampling equipment. 
HNF-4434, Rev 0

DynCorp will test and qualify each assembly to ensure that the functional criteria specified on the assembly drawing (H-2-690138) has been met.

\subsection{SOFTWARE DEVELOPMENT TASKS}

There is no software development associated with this task.

\subsection{PROCUREMENT TASKS}

The footclamp bases will be fabricated onsite by DynCorp Tri-Cities Services, Inc. The majority of any procurement associated with this task will be subcontracted to DynCorp Tri-Cities Services, Inc. for parts necessary for replacement footclamp fabrication. Any long lead items required for fabrication may be procured through LMHC Characterization Procurement. LMHC Characterization Procurement has ordered three MAXIDRILL Model 3030 Footclamps to be modified. LMHC Characterization Procurement purchased one MAXIDRILL Model 3030 Footclamp previously to determine whether the functional criteria necessary for use during RMCS were met by this particular design. This previously purchased footclamp will also be modified and qualified for core sampling use.

\subsection{INSTALLATION TASKS}

The footclamp is a portable piece of equipment and as such will not be permanently installed. The footclamp is used with the Push and Rotary Mode Core Sampling Systems, its installation is accomplished for each sampling event by the normal core sampling setup procedure. The configuration of the riser equipment to include the footclamp is managed by drawings H-2-690134 and H-2-821457.

\subsection{PRE-OPERATIONAL AND OPERATIONAL TESTS}

Pre-operational testing will consist of the acceptance testing which will be performed by DynCorp personnel. Operational testing will consist of a functional test and will be conducted by Characterization Maintenance and Operations per instructions in the installation work package. LMHC Quality Assurance will observe all testing.

\subsection{SHIPPING AND HANDLING}

After being green-tagged, the footclamp assemblies will be palletized and shipped to 2101-HV. The newly fabricated footclamps, classified as GS DID, will be segregated from the tubing spider type footclamp that is currently approved for Safety Class use.

\subsection{ACCEPTANCE FOR BENEFICIAL USE}

A formal acceptance for beneficial use process and form will be used for this task per HNF 1998d. 


\subsection{RISK ASSESSMENT}

The main envisioned risk is that the footclamp containment base will not pass pre-operational testing. Appropriate engineering rigor will be used to minimize these risks.

There is also risk associated with Addendum Five of the BIO not being approved/implemented as presumed. If Addendum Five of the BIO is not approved/implemented then the $241-Z-361$ footclamps will not be affected. However, the footclamps for RMCS use will have to be upgraded to SC assemblies and may entail additional verification/qualification documentation.

\subsection{ORGANIZATION}

Responsibilities are assigned to various organizations as identified below:

COGEMA Engineering Corporation will provide task management, engineering support and design services support.

Responsible Manager:

Responsible Engineer:
J. L. Smalley

H. F. Shumake Jr.

Lockheed Martin Hanford Corporation (LMHC) will provide funding and overall task management, Cognizant Engineer support for document review and Unreviewed Safety Question (USQ) screening preparation, and Design Authority support.

Responsible Manager:

Responsible Cognizant Manager:

Responsible Cognizant Engineer/USQ Screener:

Characterization Project Design Authority:
R. M. Boger (NUMATEC)

J. S. Schofield

R. N. Dale

G. P. Janicek

DynCorp Tri-Cities Services (DYN), Inc. will be responsible for fabrication, assembly and acceptance testing of the footclamp base assembly.
Responsible Manager:
M. A. Butterworth

\subsection{SCHEDULE}

\begin{tabular}{|l|c|c|}
\hline SUBTASK & START DATE & FINISH DATE \\
\hline Prepare development test plan and report & $3 / 10 / 99$ & $4 / 9 / 99$ \\
\hline Design/Generate Fabrication/Assembly Drawings & $3 / 24 / 99$ & $4 / 26 / 99$ \\
\hline Fabrication to include acceptance testing Z-361/CPO & $4 / 29 / 99 /-$ TBD $^{*}-$ & $7 / 14 / 99 /$ TBD $^{*}-$ \\
\hline Delivery Date Z-361/CPO & $6 / 4 / 99 /-\mathrm{TBD}^{*}-$ & $7 / 14 / 99 /$ TBD $^{*}-$ \\
\hline Closeout (ABU, Essential Drawing List, etc.) & $7 / 10 / 99$ & -TBD $^{*}-$ \\
\hline
\end{tabular}

These dates are dependent on Addendum Five of the BIO. 


\subsection{COST ESTIMATE}

Cost estimates, shown in hours, associated with this task are denoted in the table below:

\begin{tabular}{|c|c|c|c|c|c|}
\hline SUBTASK & 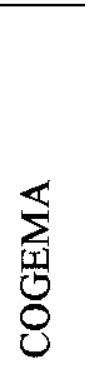 & $\sum_{=}^{U}$ & $\sum_{=}^{\mathscr{N}}$ & 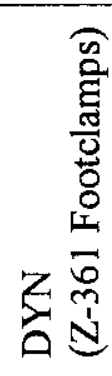 & 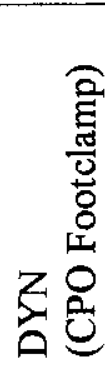 \\
\hline Issue ETP & 40 & 10 & & & \\
\hline Fabrication Drawings & 60 & 20 & 12 & & \\
\hline Assembly Drawings & 30 & 10 & 16 & & \\
\hline Fabrication & 20 & & & $\$ 54 \mathrm{k}$ & $\$ 20 \mathrm{k}$ \\
\hline Closeout Tasks & 30 & & & & \\
\hline TOTAL & 180 & 40 & 28 & $\$ 54 \mathrm{k}$ & $\$ 20 \mathrm{k}$ \\
\hline
\end{tabular}

Costs for installation and life cycle are not included in this cost estimate because they are funded by Characterization Project Operations.

\subsection{DEVELOPMENT CONTROL REQUIREMENTS}

Below is a list of requirements that must be identified in the work plan for any FacilityUse item per HNF 1999a. After each item is a description of where the information can be found, including within this ETP, HNF-4434.

- Description of the work to be performed

- Restrictions and/or special conditions

- Inspection/fabrication criteria

- Work Order Number

- Material Requirements

- Special Testing Requirements

- Safety Class
Pre-released version of Drawing $\mathrm{H}-2-690138$, and HNF-4434, Sec. 3.0

None.

Fabrication Request (J-10) and HNF-4434, Sec. 9.0

Fabrication Request (J-10) and HNF-4434, Sec. 12.0

Pre-released version of Drawing H-2-690138

HNF-4434, Sec. 3.7 and Pre-released version of Drawing H-2-690138

Fabrication Request (J-10) and HNF-4434, Sec. 10.0 
- Approval Designator

- Shipping and Handling Instructions

- Delivery Date
Fabrication Request (J-10) and HNF-4434, Sec. 9.0 and 10.0

Fabrication Request (J-10) and HNF-4434, Sec. 3.8

HNF-4434, Sec. 5.0

Only Characterization Engineering personnel shall have signature authority on any "redline" changes.

\subsection{CONFIGURATION MANAGEMENT}

Configuration management will comply with the requirements in engineering Drawing Requirements (HNF 1999b) and Engineering Document Change Control Requirements (HNF 1997a).

\subsection{QUALITY ASSURANCE}

Quality Assurance review of tasks will be determined on a task-by-task basis per Review and Approval of documents (HNF 1997c). The cognizant engineer will assign approval designators for all documentation with concurrence from the cognizant manager and design authority. All documents assigned an approval designator " $Q$ " shall be reviewed and approved by Quality Assurance.

\subsection{SAFETY AND AUTHORIZATION BASIS}

Safety review will be determined on a task-by-task basis per Review and Approval of Documents (HNF 1997c). The cognizant engineer will assign approval designators for all documentation with concurrence from the cognizant manager and design authority. All documents assigned an approval designator " $\mathrm{S}$ " shall be reviewed and approved by Safety.

No authorization basis or permitting documentation changes are anticipated, however, an Unreviewed Safety Question Screening/Determination will be completed on any changes made.

\subsection{SYSTEM ENGINEERING}

This task plan defines the work required to design, generate drawings, fabricate and assemble a footclamp containment base for use during RMCS operations. The footclamp interfaces with the sampling equipment are shown on Drawings H-2-690134 and H-2-821457. The existing design requirements are included in the DCM (HNF 1998a). This activity supports the Tank Farms task identified in the Work Breakdown Structure (WBS) as task number 1.1.1.1.1.3.1.9, Engineering, Troubleshooting and Design Assistance (HNF 1998f). 


\subsection{CLOSEOUT COSTS}

Closeout costs could vary depending on when closeout occurred but would be limited to less than 100 hours. The closeout costs could include time to ensure that partially completed datasets, ECNs, and work packages are placed in a retrievable condition. 
HNF-4434, Rev 0

\subsection{REFERENCES}

Drawing, Unreleased, H-2-690138, Footclamp Assembly (RMCST), Hanford Site, Richland, WA

Drawing, Hanford Document Control, H-2-690134, Drill String Arrangements (RMCST), Hanford Site, Richland, WA

Drawing, Hanford Document Control, H-2-821457, Drill String Arrangements

(Truck \#2), Hanford Site, Richland, WA

HNF, 1997a, HNF-PRO-440, Rev. 1, Project Hanford Policy and Procedure System, Engineering Document Change Control Requirements,

Fluor Daniel Hanford, Inc., Richland, WA

HNF, 1997b, HNF-PRO-245, Rev. 1, Project Hanford Policy and Procedure System,

Design Verification Requirements, Fluor Daniel Hanford, Inc., Richland, WA

HNF, 1997c, HNF-PRO-233, Rev. 1, Project Hanford Policy and Procedure System,

Review and Approval of Documents, Fluor Daniel Hanford, Inc., Richland, WA

HNF, 1998a, HNF-SD-WM-CR-062, Rev. 1, Baseline Design Compliance Matrix For

The Rotary Mode Core Sampling System, Lockheed Martin Hanford Corporation, Richland, WA

HNF, 1998b, HNF-3240, Rev. 2, Characterization Equipment Essential/Support

Drawing Plan, Lockheed Martin Hanford Corporation, Richland, WA

HNF, 1998c, HNF-2305, Rev. 0, Drawing Evaluation Report for Sampling Equipment Drawings, Lockheed Martin Hanford Corporation, Richland, WA

HNF, 1998d, HNF-IP-0842, Vol. IV, TWRS Administration, Sec 3.12, Acceptance of Structures, Systems and components for Beneficial Use, Lockheed Martin Hanford Corporation, Richland, WA

HNF, 1998e, HNF-SD-WM-SEL-044, Rev. 2, A Safety Equipment List for Rotary Mode Core Sampling Systems Operation in Single Shell Flammable Gas Tanks, COGEMA Engineering Corporation; Richland, WA

HNF, 1998f, HNF-SP-1230, Rev. 1, Tank Waste Remediation System Waste

Characterization Fiscal Year 1999 Multi-Year Work Plan WBS 1.1, Lockheed Martin Hanford Corporation; Richland, WA

HNF, 1999a, HNF-IP-0842, Vol. IV, TWRS Administration, Sec. 4.27, Development Control Requirements, Lockheed Martin Hanford Corporation, Richland, WA 
HNF, 1999b, HNF-IP-0842, Vol. IV, TWRS Administration, Sec. 4.25, Engineering Drawings, Lockheed Martin Hanford Corporation, Richland, WA

HNF, 1999c, HNF-IP-0842, Vol. IV, TWRS Administration, Sec. 4.28, Testing Practices Requirements, Lockheed Martin Hanford Corporation, Richland, WA

WHC, 1997, WHC-SD-WM-SAD-035, Rev. 0-b, A Safety Assessment of Rotary Mode Core Sampling in Flammable Gas Single Shell Tanks: Hanford Site, Richland, Washington, Westinghouse Hanford Corporation, Richland, WA 
HNF-4434, Rev 0

14.0 APPENDIX A-ACCEPTANCE FOR BENENFICIAL USE 


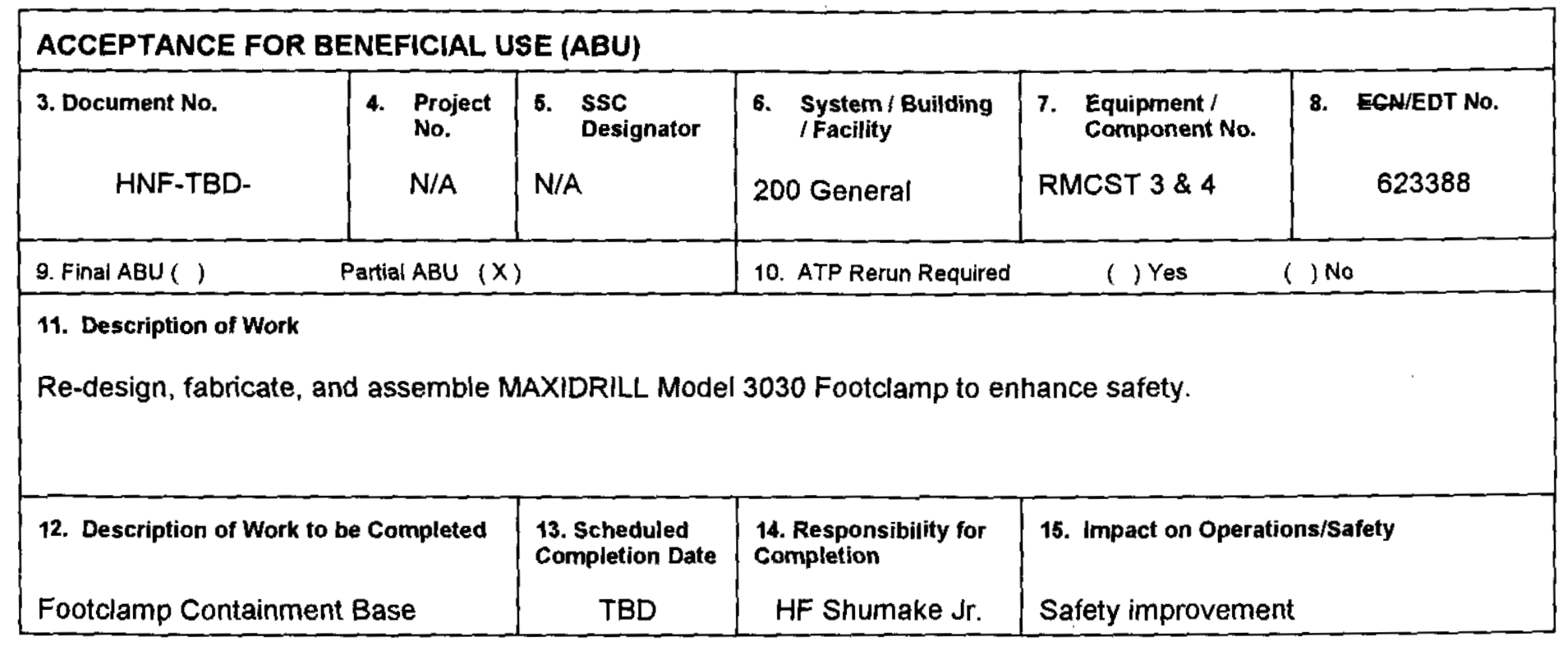

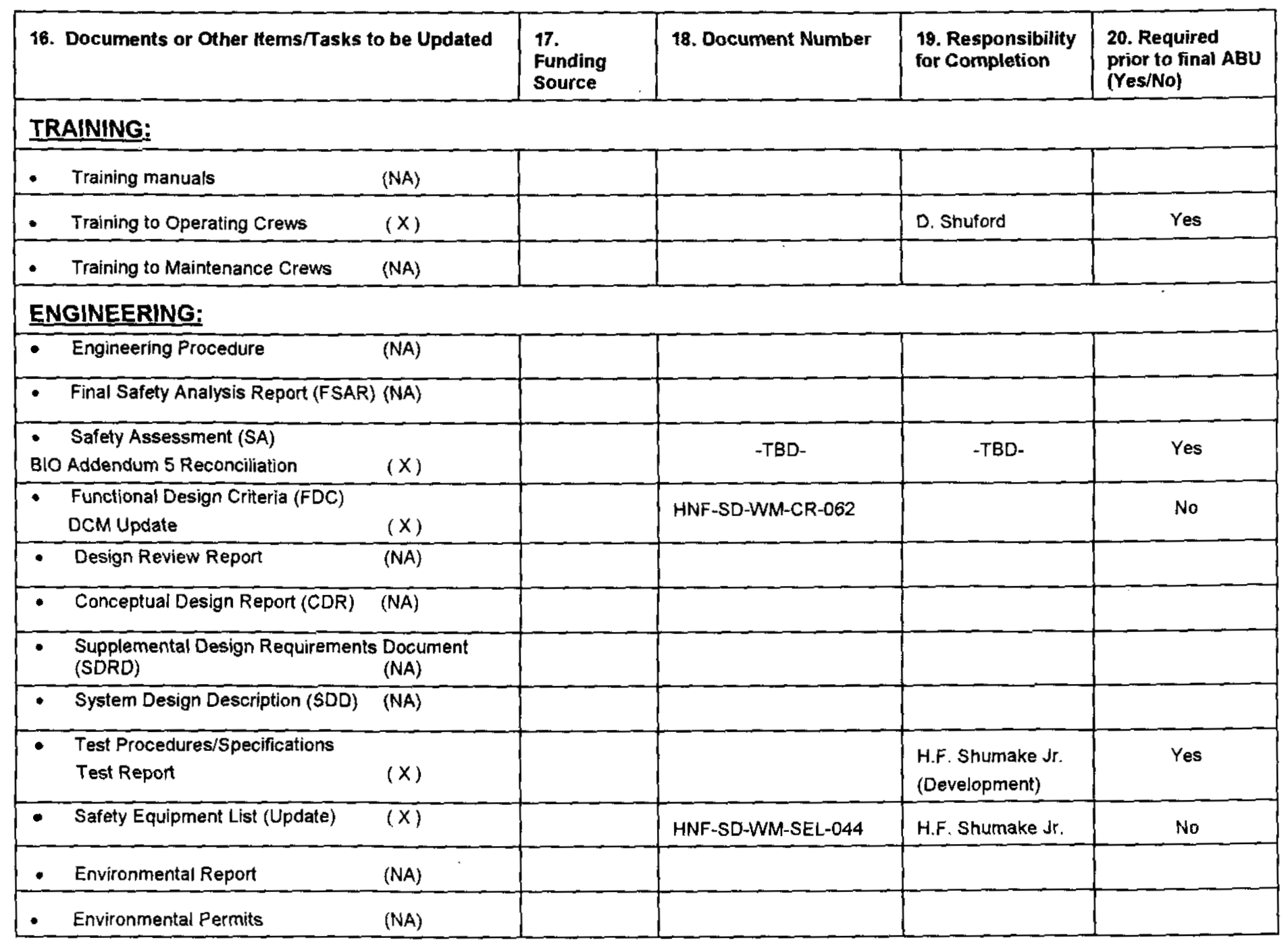


HNF-4434, Rev 0

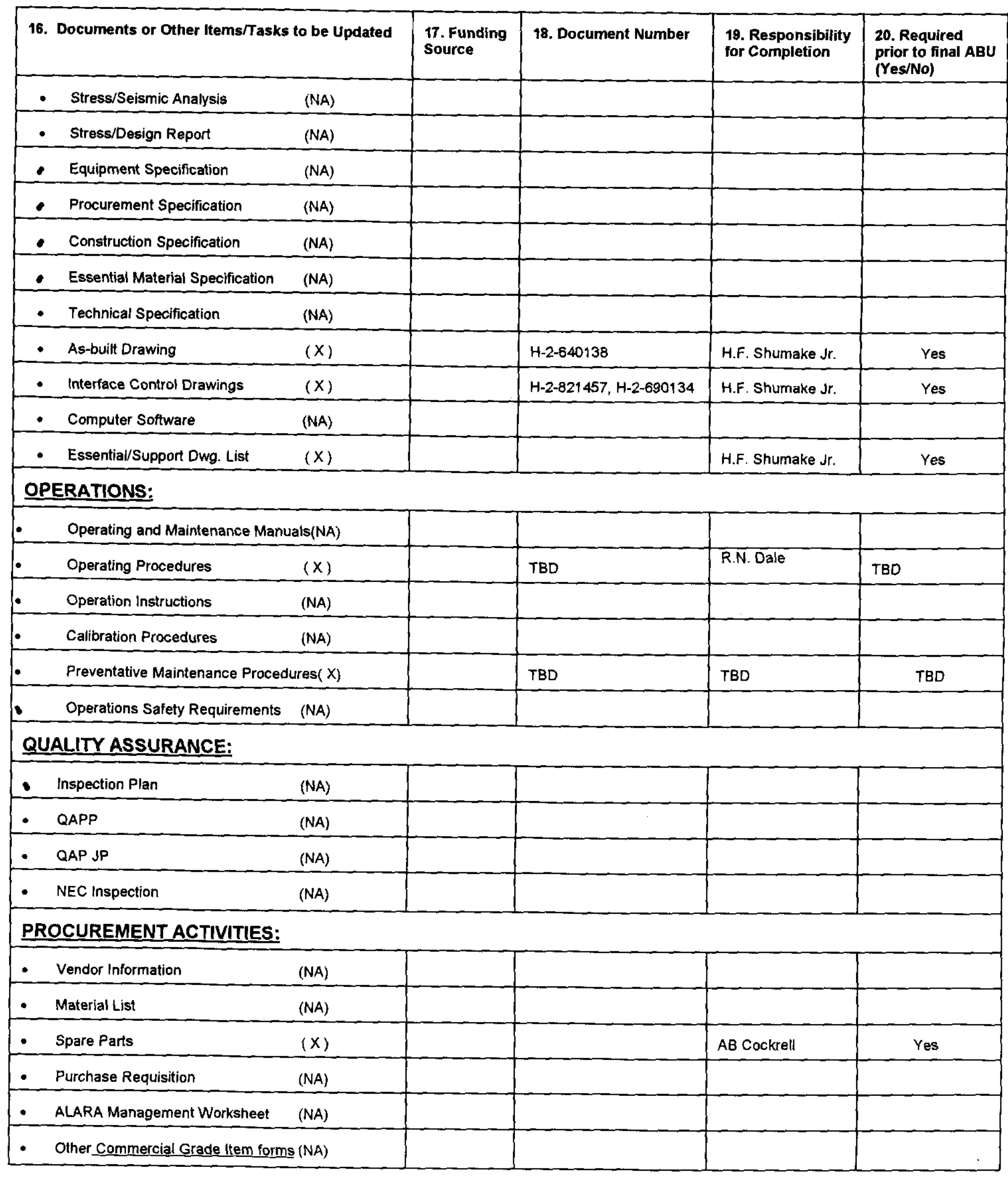


HNF-4434, Rev 0

\section{PROJECTS: CHARACTERIZATION OPERATIONS AND ENGINEERING}

\section{Signature}

Date

Cog/Field Engineer R.N. Dale

Cog/Field Mgr. J.S. Schofield

QA J.S. Sparks

Safety J.A. Ranschau

Modification Projects R.M. Boger

Design Authority G.P. Janicek

Operations, D.H. Shuford

Design Engineer H.F. Shumake Jr. 